\title{
Stress hardening under long-term cadmium treatment is correlated with the activation of antioxidative defence and iron acquisition of chloroplasts in Populus
}

DOI 10.1515/znc-2016-0092

Received May 10, 2016; revised July 17, 2016; accepted July 17, 2016

\begin{abstract}
Cadmium (Cd), a highly toxic heavy metal affects growth and metabolic pathways in plants, including photosynthesis. Though $\mathrm{Cd}$ is a transition metal with no redox capacity, it generates reactive oxygen species (ROS) indirectly and causes oxidative stress. Nevertheless, the mechanisms involved in long-term Cd tolerance of poplar, candidate for $\mathrm{Cd}$ phytoremediation, are not well known. Hydroponically cultured poplar (Populus jacquemontiana var. glauca cv. 'Kopeczkii') plants were treated with $10 \mu \mathrm{M}$ $\mathrm{Cd}$ for 4 weeks. Following a period of functional decline, the plants performed acclimation to the $\mathrm{Cd}$ induced oxidative stress as indicated by the decreased leaf malondialdehyde (MDA) content and the recovery of most photosynthetic parameters. The increased activity of peroxidases (PODs) could have a great impact on the elimination of hydrogen peroxide, and thus the recovery of photosynthesis, while the function of superoxide dismutase (SOD) isoforms seemed to be less important. Re-distribution of the iron content of leaf mesophyll cells into the chloroplasts contributed to the biosynthesis of the photosynthetic apparatus and some antioxidative enzymes. The delayed increase in photosynthetic activity in relation to the decline in the
\end{abstract}

*Corresponding author: Ádám Solti, Department of Plant Physiology and Molecular Plant Biology, Institute of Biology, Eötvös Loránd University, Pázmány P. Lane 1/C Budapest, 1117, Hungary,

E-mail: adam.solti@ttk.elte.hu

Éva Sárvári, Ferenc Fodor and Zoltán Szigeti: Department of Plant Physiology and Molecular Plant Biology, Institute of Biology, Eötvös Loránd University, Pázmány P. Lane 1/C Budapest, 1117, Hungary Erzsébet Szöllősi and Ilona Mészáros: Department of Botany, Institute of Biology and Ecology, Faculty of Sciences and Technology, University of Debrecen, P.O. Box: 14 Debrecen, 4010, Hungary Brigitta Tóth: Department of Agricultural Botany, Crop Physiology and Biotechnology, Institute of Crop Sciences, Faculty of Agricultural and Food Sciences and Environmental Management, University of Debrecen, Böszörményi Street 138, Debrecen, 4032, Hungary level of lipid peroxidation indicates that elimination of oxidative stress damage by acclimation mechanisms is required for the restoration of the photosynthetic apparatus during long-term $\mathrm{Cd}$ treatment.

Keywords: cadmium; oxidative stress; photosynthesis; Populus; stress hardening.

Dedicated to the memory of Professor Peter Böger, honorary member of the Hungarian Society of Plant Biology.

\section{Introduction}

Many cultivated plant species have to cope with increased soil cadmium (Cd) concentration due to anthropogenic activities, such as deposition of industrial wastes (galvanic batteries, dyes), usage of chemical fertilisers in intensive agricultural production, and zinc mining, where $\mathrm{Cd}$ is a by-product. Cd contamination has increasing importance because of its toxicity to plants as well as the high risk to human health [1]. In plants, Cd causes various kinds of damage (see [2] for recent review). Among them, the disturbance of metal homeostasis, causing iron deficiency in the shoot [3, 4], is of primary importance. As a result, the biosynthesis of chlorophylls (Chls), the formation of Chl-protein complexes and the development of thylakoid membranes are highly disturbed [5, 6]. Particularly, Cd was shown to selectively inhibit the biogenesis of photosystem I (PSI) and the activity of PSII reaction centres [7], as well as to retard $\mathrm{CO}_{2}$ fixation [8]. Once photosynthesis becomes inactivated, the generation and accumulation of reactive oxygen species (ROS) is elevated. Cd was shown to cause serious oxidative damage in the shoot [9]. In the chloroplasts, one of the most important targets of ROS is the D1 protein in PSII [10]. Under mild stress conditions, damaged D1 proteins are replaced with new ones resulting in functioning PSII complexes. Under constant stress, however, the repair capacity is not high enough to replace 
all the inactivated centres. In addition to the non-photochemical quenching (NPQ) processes in the antennae, these inactivated reaction centres are strong quenchers of the excited state of the antennae that may protect the neighbouring active PSII complexes [11, 12].

In aerobic cells, ROS are common by-products of biochemical processes, but a well-equipped antioxidative system has evolved to maintain the redox equilibrium. There are several pathways for the elimination of ROS in mesophyll cells, such as the water-water cycle in the chloroplasts operated by superoxide dismutase (SOD) and ascorbate peroxidase (APX) isoforms [13]. Moreover, catalases (CATs) and glutathione peroxidases located in the peroxisomes [14] also contribute to the protection against oxidative stress. Parallel to the occurrence of damage, organisms have to increase the activity of their defence mechanisms in order to restore vital functions and to avoid serious and lethal damage. $\mathrm{Cd}$, which is able to provoke the disruption of redox equilibrium, has strong effects on antioxidative defence [14-16]. Moderate $\mathrm{Cd}$ stress has been found to increase the levels of defence metabolites, and to activate guaiacol peroxidase, syringaldazine peroxidase, APX and glutathione reductase in Phaseolus vulgaris [15] and poplar [17]. However, the observed responses are not unambiguous. In tomato, activities of glutathione reductase (GR), CAT and APX increased under Cd stress, and those of peroxidases (PODs), which require iron for their heme cofactors, decreased [18], while expression and activity of the latter increased in poplar under long-term Cd treatment $[19,20]$.

Poplar species are good candidates for $\mathrm{Cd}$ phytoremediation [21]. As Cd phytoremediation requires plants that exhibit long-term resistance to Cd stress, an understanding of defence mechanisms allowing the plant to overcome the stress-induced damages is essential. Yet the causal relationship between the alleviation of Cd-induced inhibition of photosynthesis and the activities of protective mechanisms is poorly known in poplars $[19,20]$. Therefore, we have investigated here in some detail changes in excitation energy allocation and in the activities of antioxidant enzymes under long-term moderate Cd stress.

\section{Materials and methods}

\subsection{Plant material}

Experiments were performed on micropropagated poplar [Populus jacquemontiana var. glauca (Haines) Kimura cv. 'Kopeczkii'] plants, grown hydroponically in a climate chamber [14/10 h light $\left(100 \mu \mathrm{mol}\right.$ photons $\left.\mathrm{m}^{-2} \mathrm{~s}^{-1}\right) /$ dark period, $24 / 22{ }^{\circ} \mathrm{C}$ and $70 / 75 \%$ relative humidity] in quarterstrength Hoagland solution $\left[1.25 \mathrm{mM} \mathrm{Ca}\left(\mathrm{NO}_{3}\right)_{2}, 1.25 \mathrm{mM}\right.$ $\mathrm{KNO}_{3}, 0.5 \mathrm{mM} \mathrm{MgSO}_{4}, 0.25 \mathrm{mM} \mathrm{KH}_{2} \mathrm{PO}_{4}, 0.08 \mu \mathrm{M} \mathrm{CuSO}_{4}$, $4.6 \mu \mathrm{M} \mathrm{MnCl}_{2}, 0.19 \mu \mathrm{M} \mathrm{ZnSO}_{4}, 0.12 \mu \mathrm{M} \mathrm{Na}{ }_{2} \mathrm{MoO}_{4}, 11.56 \mu \mathrm{M}$ $\mathrm{H}_{3} \mathrm{BO}_{3}$ and $10 \mu \mathrm{M} \mathrm{Fe}^{(\mathrm{IIII})}$-citrate as iron source]. Control plants (Ctrl) and plants treated with $10 \mu \mathrm{M} \mathrm{Cd}\left(\mathrm{NO}_{3}\right)_{2}$ from their four-leaf stage (Cad plants) were investigated for a 4-week period. Data were collected on the respective $6^{\text {th }}$ leaves, emerged during the time of treatment.

\subsection{Determination of element concentrations}

Dried ( 1 week at $60{ }^{\circ} \mathrm{C}$ ) leaves were digested by $\mathrm{HNO}_{3}$ for 30 min at $60{ }^{\circ} \mathrm{C}$, and then in $\mathrm{H}_{2} \mathrm{O}_{2}$ for 90 min at $120{ }^{\circ} \mathrm{C}$. After filtration through MN $640 \mathrm{~W}$ paper, ion contents were measured by ICP-MS (Inductively Connected Plasma Mass Spectrometer, Thermo-Fisher, Waltham, MA, USA).

For measurement of chloroplast iron content, leaves were homogenised in isolation buffer [50 $\mathrm{mM}$ 4-(2hydroxyethyl)-1-piperazineethanesulfonic acid (HEPES)$\mathrm{KOH}, \mathrm{pH}$ 7.0, $330 \mathrm{mM}$ sorbitol, $2 \mathrm{mM}$ ethylenediaminetetraacetic acid (EDTA), $2 \mathrm{mM} \mathrm{MgCl}, 0.1 \%(\mathrm{w} / \mathrm{v})$ bovine serum albumine (BSA), $0.1 \%(\mathrm{w} / \mathrm{v})$ Na-ascorbate] in a Waring Blendor for $5 \mathrm{~s}$. The homogenate was filtered through four layers of gauze and two layers of Miracloth (CalbiochemNovabiochem, San Diego, CA, USA), and centrifuged at $1500 \times g$ for $5 \mathrm{~min}$. All centrifugation steps were carried out in a swing-out rotor. The pellet was resuspended in washing buffer (50 mM HEPES-KOH, pH 7.0, 330 mM sorbitol, $2 \mathrm{mM} \mathrm{MgCl}$ ), layered on top of a stepwise sucrose gradient (50 mM HEPES-KOH, pH 7.0, 20/45/60\% sucrose, $2 \mathrm{mM}$ EDTA, $2 \mathrm{mM} \mathrm{MgCl}$ ), and centrifuged at $2000 \times \mathrm{g}$ for $15 \mathrm{~min}$. Intact chloroplasts were collected from the $45 / 60 \%$ sucrose interface. After five-time dilution with washing buffer, the plastid fraction was centrifuged at $2500 \times g$ for $5 \mathrm{~min}$. The pellet was resuspended in washing buffer. The number of chloroplasts was counted in a Bürker chamber in a Nikon Optiphot-2 microscope (Zeiss Apochromatic 40/0.95 160/0.17 objective; Carl Zeiss, Jena, Germany) equipped with a Nikon D70 DSLR camera. Chloroplasts were solubilised in $1 \%$ SDS, $1 \%$ DTT at room temperature for $30 \mathrm{~min}$. Non-solubilised material (starch) was removed by centrifugation at $10,000 \times g$ for $5 \mathrm{~min}$. As described in Sárvári et al. [22], the iron content of solubilised chloroplast material was measured photometrically in form of the $\left[\mathrm{Fe}(\mathrm{BPDS})_{3}\right]^{4-}$ complex at $535 \mathrm{~nm}$ in a UV-VIS spectrophotometer (Shimadzu, Kyoto, Japan) after the addition of $100 \mu \mathrm{M}$ ascorbic acid to reduce the total iron content of the samples to $\mathrm{Fe}^{2+}$ and $300 \mu \mathrm{M}$ bathophenanthroline 
disulphonate (BPDS) disodium salt (Sigma-Aldrich, St. Louis, MO, USA). Steady-state absorbance was reached after 60 min incubation in darkness at room temperature. An absorption coefficient of $22.14 \mathrm{mM}^{-1} \mathrm{~cm}^{-1}$ for the $\mathrm{Fe}^{(\mathrm{II})}$ BPDS complex [23] was used.

\subsection{Pigment contents}

The Chls of leaf discs were determined spectrophotometrically in $80 \%(\mathrm{v} / \mathrm{v})$ aqueous acetone extracts containing $5 \mathrm{mM}$ Tricine- $\mathrm{KOH}$ buffer, $\mathrm{pH} 7.8$, using the absorption coefficients of Porra et al. [24].

For the determination of xanthophyll cycle components, leaf discs adapted to $100 \mu \mathrm{mol}$ photons $\mathrm{m}^{-2} \mathrm{~s}^{-1}$ or kept in dark for 30 min were used. Carotenoid components were separated by HPLC method and quantified using zeaxanthin as standard $[25,26]$. The de-epoxidation state of xanthophyll cycle pigments (DEEPS) was calculated as $(\mathrm{DEEPs}=\mathrm{Z}+0.5 \mathrm{~A}) /(\mathrm{V}+\mathrm{A}+\mathrm{Z})$ and diurnal change as $\triangle$ DEEPS $=$ DEEPS $_{\text {light }}-$ DEEPS $_{\text {dark }}$.

\subsection{Chlorophyll $a$ fluorescence induction}

Fluorescence induction measurements were carried out with intact leaves using a PAM 101-102-103 Chlorophyll Fluorometer (Walz, Effeltrich, Germany). Leaves were dark-adapted for $30 \mathrm{~min}$. The $\mathrm{F}_{0}$ level of fluorescence was determined by switching on the measuring light with a modulation frequency of $1.6 \mathrm{kHz}$ and a photosynthetic photon flux density (PPFD) of $<1 \mu \mathrm{mol} \mathrm{m}^{-2} \mathrm{~s}^{-1}$ after $3 \mathrm{~s}$ illumination with far-red light in order to eliminate reduced electron carriers. The maximum fluorescence yields, $\mathrm{F}_{\mathrm{m}}$ in the dark-adapted state and $\mathrm{F}_{\mathrm{m}}{ }^{\prime}$ in light-adapted state, were measured by applying a $0.7 \mathrm{~s}$ pulse of white light (PPFD of $3500 \mu \mathrm{mol}$ photon $\mathrm{m}^{-2} \mathrm{~s}^{-1}$, light source: KL 1500 electronic, Schott, Mainz, Germany). The maximal and actual efficiency of PSII centres were determined as $F_{v} / F_{m}=\left(F_{m}-\right.$ $\left.\mathrm{F}_{\mathrm{o}}\right) / \mathrm{F}_{\mathrm{m}}$ and $\Delta \mathrm{F} / \mathrm{F}_{\mathrm{m}}{ }^{\prime}=\left(\mathrm{F}_{\mathrm{m}}{ }^{\prime}-\mathrm{F}_{\mathrm{t}}\right) / \mathrm{F}_{\mathrm{m}}{ }^{\prime}$, respectively. For quenching analysis, actinic white light (PPFD of $100 \mu$ mol photon $\mathrm{m}^{-2} \mathrm{~s}^{-1}$, KL 1500 electronic) was provided. Simultaneously with the onset of actinic light, the modulation frequency was switched to $100 \mathrm{kHz}$. The steady-state fluorescence of the light-adapted state $\left(F_{t}\right)$ was determined when no change was found in $\mathrm{F}_{\mathrm{m}}{ }^{\prime}$ values between two white light flashes separated by $100 \mathrm{~s}$. Considering that all stress factors inhibiting photosynthesis also cause light stress, the quenching parameters of Hendrickson et al. [27] were used for assessing the allocation of excitation energy in all samples as follows:

$$
\begin{aligned}
\Phi_{\mathrm{PSII}} & =\left(1-\frac{\mathrm{F}_{\mathrm{t}}}{\mathrm{F}_{\mathrm{m}}{ }^{\prime}}\right) \star\left(\frac{\mathrm{F}_{\mathrm{v}} / \mathrm{F}_{\mathrm{m}}}{\mathrm{F}_{\mathrm{vM}} / \mathrm{F}_{\mathrm{mM}}}\right) ; \\
\Phi_{\mathrm{NPQ}} & =\left(\frac{\mathrm{F}_{\mathrm{t}}}{\mathrm{F}_{\mathrm{m}}{ }^{\prime}}-\frac{\mathrm{F}_{\mathrm{t}}}{\mathrm{F}_{\mathrm{m}}}\right) \star\left(\frac{\mathrm{F}_{\mathrm{v}} / \mathrm{F}_{\mathrm{m}}}{\mathrm{F}_{\mathrm{vM}} / \mathrm{F}_{\mathrm{mM}}}\right) ; \\
\Phi_{\mathrm{f}, \mathrm{D}} & =\left(\frac{\mathrm{F}_{\mathrm{t}}}{\mathrm{F}_{\mathrm{m}}}\right) \star\left(\frac{\mathrm{F}_{\mathrm{v}} / \mathrm{F}_{\mathrm{m}}}{\mathrm{F}_{\mathrm{vM}} / \mathrm{F}_{\mathrm{mM}}}\right) ; \\
\Phi_{\mathrm{NF}} & =1-\left(\frac{\mathrm{F}_{\mathrm{v}} / \mathrm{F}_{\mathrm{m}}}{\mathrm{F}_{\mathrm{vM}} / \mathrm{F}_{\mathrm{mM}}}\right) ;
\end{aligned}
$$

$\Phi_{\text {PSII }}$, the photochemical efficiency of functional PSII centres; $\Phi_{\mathrm{NP},}, \Delta \mathrm{pH}$ dependent, xanthophyll-cycle coupled non-photochemical quenching; $\Phi_{\mathrm{f}, \mathrm{D}}$, fluorescence/thermal dissipation of the absorbed energy; $\Phi_{\mathrm{NF}}$, the thermal dissipation by inactive PSII centres. The intensity of actinic light $\left(100 \mu \mathrm{mol}\right.$ photon $\left.\mathrm{m}^{-2} \mathrm{~s}^{-1}\right)$ corresponded to the light intensity supporting optimal growth of Cad plants. $\mathrm{F}_{\mathrm{vM}} /$ $\mathrm{F}_{\mathrm{mm}}$ was applied as the mean of $\mathrm{F}_{\mathrm{v}} / \mathrm{F}_{\mathrm{m}}$ values of Ctrl (quasi non-inhibited) plants according to Solti et al. [28].

\subsection{Oxidative damage and antioxidative defence}

Lipid peroxidation was assessed by measuring the malondialdehyde (MDA) content according to Heath and Packer [29]. Leaf samples of $100 \mathrm{mg}$ were homogenised in $1 \mathrm{ml} \mathrm{0.1 \%} \mathrm{(w/v)} \mathrm{trichloroacetic} \mathrm{acid} \mathrm{and} \mathrm{centrifuged} \mathrm{at}$ $15,000 \times g$ for $15 \mathrm{~min}$. Equal volumes of $20 \%$ (v/v) trichloroacetic acid and $0.5 \%(\mathrm{w} / \mathrm{v})$ thiobarbiturate were added to the supernatant and the mixtures incubated at $90^{\circ} \mathrm{C}$ for $30 \mathrm{~min}$. The MDA content was determined by measuring the absorption at $532 \mathrm{~nm}\left(\varepsilon=155 \mathrm{mM}^{-1} \mathrm{~cm}^{-1}\right)$.

The activity of APX (L-ascorbate: $\mathrm{H}_{2} \mathrm{O}_{2}$ oxidoreductase, EC 1.11.1.11) was measured according to Nakano and Asada [30]. Leaf samples of $100 \mathrm{mg}$ were homogenised in $1 \mathrm{ml}$ isolating buffer [ $50 \mathrm{mM}$ phosphate buffer, $\mathrm{pH}$ 7.0, $1.0 \mathrm{mM}$ EDTA, 0.1\% (w/v) Triton X-100, $5 \mathrm{mM}$ ascorbic acid, $2 \mathrm{mM}$ PVP] at $0{ }^{\circ} \mathrm{C}$. Reaction mixtures contained $50 \mathrm{mM}$ phosphate buffer ( $\mathrm{pH}$ 7.0), $0.1 \mathrm{mM} \mathrm{H}_{2} \mathrm{O}_{2}, 0.5 \mathrm{mM}$ ascorbic acid, $0.1 \mathrm{mM}$ EDTA and $100 \mu \mathrm{l}$ crude enzyme extract. The reaction was started by adding $\mathrm{H}_{2} \mathrm{O}_{2}$. Enzyme activity was measured by following the absorption decrease of ascorbate at $290 \mathrm{~nm}\left(\varepsilon=2.8 \mathrm{mM}^{-1} \mathrm{~cm}^{-1}\right)$ at $25^{\circ} \mathrm{C}$.

The activity of SOD (EC 1.15.1.1) was measured according to Giannopolitis and Ries [31] with some modifications. Leaf samples of $100 \mathrm{mg}$ were homogenised on ice in $1 \mathrm{ml}$ isolating buffer (as above, with omission of ascorbate) and centrifuged at $15,000 \times g$ for $15 \mathrm{~min}$, and the supernatants were collected as crude extract. Samples 
were solubilised mildly ( $5 \mathrm{mM}$ Tris- $\mathrm{HCl}, \mathrm{pH} 6.8,0.01 \%$ SDS, 10\% glycerol and 0.001\% bromophenol blue). SOD isoforms were separated by native PAGE in $10-18 \%$ gradient acrylamide gels according to Laemmli [32], but containing only $0.01 \%$ SDS. Gels were negatively stained for SOD activity in $50 \mathrm{mM}$ phosphate buffer ( $\mathrm{pH} 7.8$ ), $0.1 \mathrm{mM}$ EDTA, $13 \mathrm{mM}$ methionine, $60 \mu \mathrm{M}$ riboflavin, and $2.25 \mathrm{mM}$ nitro blue tetrazolium chloride. Gels stained for activity were scanned using an Epson Perfection V750 PRO gel scanner and evaluated by densitometry using the Phoretix software (Phoretix International, Newcastle upon Tyne, UK).

To extract and separate PODs (EC 1.11.1.7), the same procedure was employed as described for the SOD isoforms. POD isoforms were stained by incubating the native gels in $50 \mathrm{mM}$ acetate buffer ( $\mathrm{pH} 4.5$ ), containing $2 \mathrm{mM}$ benzidine (dissolved in DMSO). The reaction was initiated by adding $3 \mathrm{mM} \mathrm{H}_{2} \mathrm{O}_{2}$ and allowed to continue for $30 \mathrm{~min}$ [33]. Bands were evaluated by densitometry using the Phoretix software as above.

To measure protein contents of samples, solubilised proteins (in $5 \mathrm{mM}$ Tris- $\mathrm{HCl}, \mathrm{pH} 6.8 \%$ SDS, 2\% dithiothreitol, $10 \%$ glycerol and $0.001 \%$ bromophenol blue) were run on 10-18\% gradient acrylamide gels containing 0.1\% SDS [32]. Protein content was calculated by comparing the density of protein samples to that of protein standards of known protein content in Coomassie-stained gels.

\subsection{Statistical analysis}

Enzymatic activities, pigment and element contents were measured in two replicates of three to four independent experiments. Fluorescence induction measurements were performed on the same 4-5 plants during the experimental period in three independent experiments. Unpaired Student's t-tests and one-way ANOVAs with Tukey-Kramer post-hoc tests were performed by InStat v. 3.00 (GraphPad Software, Inc.). The term 'significantly different' means $\mathrm{p}<0.05$.

\section{Results}

\subsection{Leaf development}

Investigations were performed on the respective $6^{\text {th }}$ leaves developed during the treatment period. The rate of leaf growth, both with respect to weight and area, began to decline in leaves of Cad plants from the beginning of the treatment. Cad and Ctrl $6^{\text {th }}$ leaves reached their maximal size on the $9-10^{\text {th }}$ and $10-11^{\text {th }}$ day of treatment, respectively, thus no further growth was observed (the maximal sizes of Cad leaves were $58.1 \pm 2.3 \mathrm{~cm}^{2}$ area and $518.6 \pm 20.6 \mathrm{mg}$ fresh weight, respectively, and those of Ctrl leaves were $129.1 \pm 6.1 \mathrm{~cm}^{2}$ and $785.7 \pm 168.26 \mathrm{mg}$, respectively). In Ctrl leaves, the dry weight increased in parallel to the fresh weight (reaching $124.0 \pm 6.9 \mathrm{mg}$ on the $11^{\text {th }}$ day). However, in Cad leaves, the increase in the leaf dry weight did not stop in parallel with leaf expansion but continued in the second and third week of treatment, and increased from $52.0 \pm 1.7 \mathrm{mg}\left(7^{\text {th }}\right.$ day of treatment) to $88.9 \pm 1.2 \mathrm{mg}$ ( $21^{\mathrm{st}}$ day of treatment). The detailed changes in leaf areas and weights are found in Supplementary Material 1.

\subsection{Leaf metal content}

The concentration of $\mathrm{Cd}$ reached $268.0 \pm 45.9 \mu \mathrm{g} \mathrm{g}^{-1}$ dry weight (DW) in Cad leaves by the $7^{\text {th }}$ day and $373.0 \pm$ $43.8 \mu \mathrm{g} \mathrm{g}^{-1} \mathrm{DW}$ by the $21^{\text {st }}$ day of treatment (Figure $1 \mathrm{~A}$ ), whereas Ctrl leaves contained $<3 \mu \mathrm{g} \mathrm{Cd} \mathrm{g}^{-1}$ DW during the investigated period. Concerning the essential transition metals, the Fe concentration of leaves was strongly affected by Cd treatment (Figure 1A): it decreased to 45.0 $\pm 3.3 \%$ of the Ctrl at the $9^{\text {th }}$ day, and did not change significantly thereafter. The concentration of $\mathrm{Mn}$ in the Cad samples was hardly affected, i.e. it decreased somewhat but did not differ significantly from that of the Ctrl during the experimental period. The $\mathrm{Zn}$ concentration was elevated under $\mathrm{Cd}$ treatment, and reached $175.3 \pm 17.5 \%$ of Ctrl by the end of the third week.

\subsection{Iron content of chloroplasts}

As a result of acute Cd stress (7 day after treatment), the Fe content of the chloroplasts was strongly reduced, being around $60 \%$ of the Ctrl $(0.41 \pm 0.04$ vs. $0.67 \pm 0.04 \mathrm{fmol} \mathrm{Fe}$ chloroplast $^{-1}$ ). From the end of the first week on, however, the Fe content of chloroplasts isolated from Cad leaves started to increase (Figure 1B). It is important to mention that Fe also accumulated in Ctrl chloroplasts during the treatment period, but such an increase was more intensive in the Cad chloroplasts. Thus, by the end of the $4^{\text {th }}$ week of treatment, the Fe content in the Cad chloroplasts reached around $80 \%$ of the amount found in Ctrl chloroplasts $\left(1.23 \pm 0.05 \mathrm{fmol} \mathrm{Fe} \mathrm{chloroplast}^{-1}\right)$. 

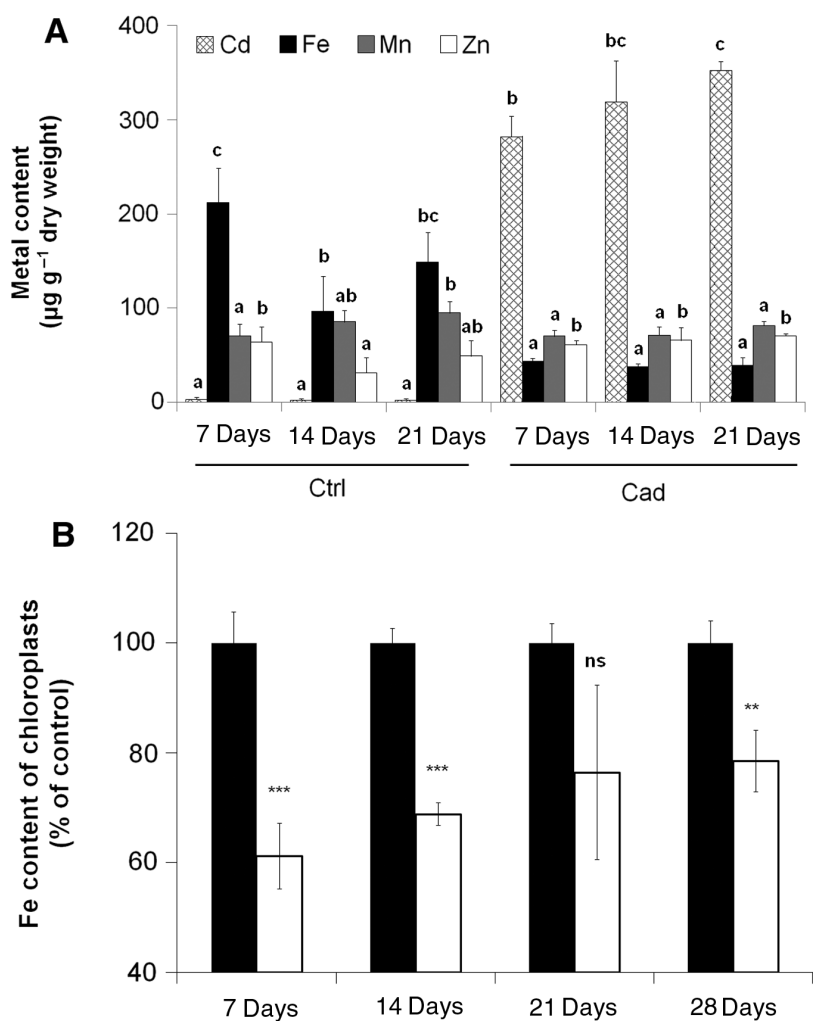

Figure 1: Changes in the metal contents. (A) Cd, Fe, Mn and $\mathrm{Zn}$ content (striped, black, grey and open columns, respectively) in Ctrl and Cad leaves in the acute phase ( $9^{\text {th }}$ day), inflexion point $\left(16^{\text {th }}\right.$ day) and hardening phase ( $20^{\text {th }}$ day) of Cd stress. Differences were analysed by one-way ANOVAs with Tukey-Kramer post-hoc tests ( $p>0.05), n=5$. Superscript letters indicate the subgroups according to the post-hoc test. (B) Fe content of the Ctrl (filled marks) and Cad chloroplasts (open marks) in the acute and hardening phase of $\mathrm{Cd}$ stress. Cad values are expressed in percent of the corresponding $\operatorname{Ctrl}(0.67 \pm 0.04 ; 0.77 \pm 0.02 ; 1.13 \pm 0.04$ and $1.23 \pm 0.05$ fmol Fe chloroplast ${ }^{-1}$ at the $7^{\text {th }}, 13^{\text {th }}, 21^{\text {st }}$ and $27^{\text {th }}$ day of treatment, respectively). Differences of the Cad samples from the corresponding controls were analysed by Student's t-test, ns, non-significant; ${ }^{\star \star} \mathrm{p}<0.05 ;{ }^{\star \star \star} \mathrm{p}<0.001 ; n=5$.

\subsection{Photosynthetic pigment content}

In Ctrl leaves, the Chl concentration did not change, or slightly increased from the middle of the second week of treatment (Figure 2A) as a result of their transformation into shade leaves. At the same time, the Chl concentration of Cad leaves was strongly reduced in the first 2 weeks, but an increasing trend was observed in the third week. Nevertheless, these leaves' Chl concentration did not reach the level of not-shaded Ctrl leaves (the difference was significant at the end of the fourth week of treatment).

$\mathrm{Cd}$ treatment also affected the $\mathrm{Chl} a / b$ ratio (Figure 2B). While the $\mathrm{Chl} a / b$ ratio increased in Ctrl leaves in the first week, some decreasing trend was found

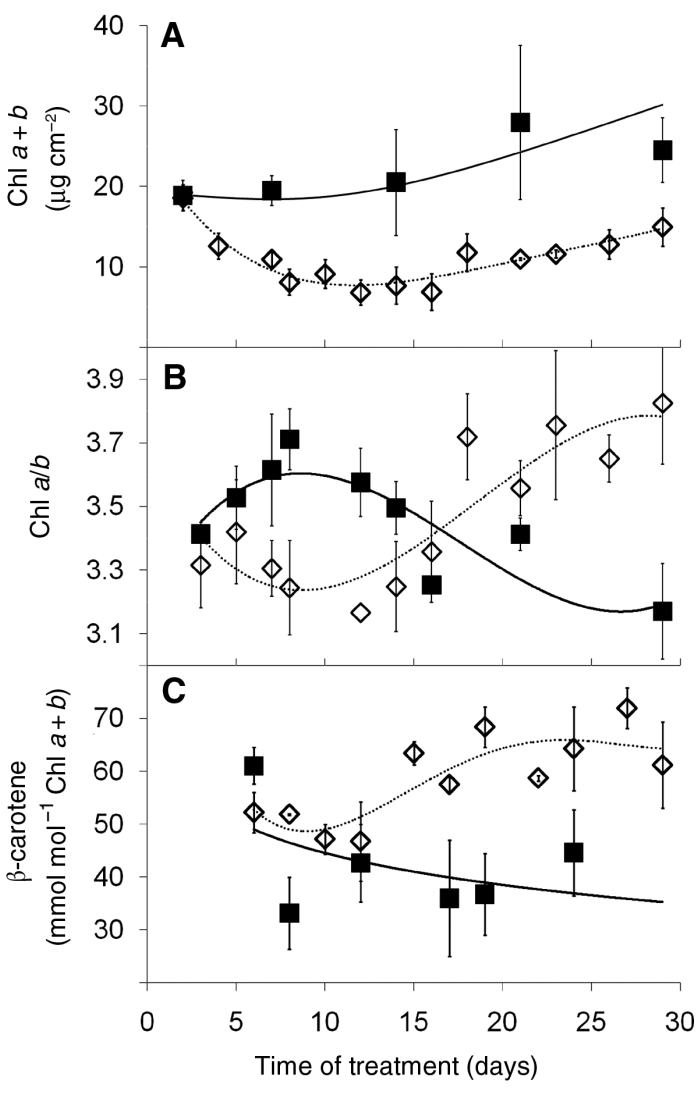

Figure 2: Changes in the pigment contents. Changes in the $\mathrm{Chl}$ $a+b$ content (per leaf area) (A), Chl $a / b$ ratio (B), and $\beta$-carotene content (per Chl $a+b$ content; $\mathrm{C}$ ) in Ctrl (filled marks) and Cad (open marks) leaves during the time of treatment. Error bars represent SD values, $n=8$.

from the second week. The ratio decreased during the first and second weeks in Cad leaves, but during the third and fourth week the relative amount of Chl $a$ increased resulting in an elevated $\mathrm{Chl} a / b$ ratio which did not differ from that of the developed (7 day-old) Ctrl (Figure 2B).

Concerning the carotenoids, the relative amount of $\beta$ carotene showed a decreasing trend in Ctrl plants during the time of treatment, whereas an increase occurred from the third week in Cad plants (Figure 2C). Cd treatment had little effect on the relative amounts of xanthophylls during the treatment period: lutein and violaxanthinantheraxanthin-zeaxanthin (VAZ) decreased in both the Ctrl and Cad plants, but the decrease was less pronounced in Cad plants (lutein and VAZ contents decreased from $142.3 \pm 32.6$ to $111.8 \pm 16.6 \mathrm{mmol}$ lutein $\mathrm{mol}^{-1} \mathrm{Chl} a+b$ and from $32.8 \pm 10.5$ to $27.4 \pm 4.5 \mathrm{mmol} \mathrm{VAZ} \mathrm{mol}^{-1} \mathrm{Chl} a+b$ in Ctrl, respectively, whereas they decreased from $159.3 \pm$ 21.5 to $139.6 \pm 10.2 \mathrm{mmol}$ lutein $\mathrm{mol}^{-1} \mathrm{Chl} a+b$ and from $41.9 \pm 10.3$ to $31.6 \pm 5.4 \mathrm{mmol} \mathrm{VAZ} \mathrm{mol}^{-1} \mathrm{Chl} a+b$ in Cad leaves; differences are not significant among the corresponding values). $\triangle$ DEEPS, indicating the light-inducible 
de-epoxidation of violaxanthin, increased in Cad plants from the second week to the end of the investigated period (from $0.359 \pm 0.050$ to $0.744 \pm 0.159$, difference is significant), thus becoming significantly higher than the Ctrl value by the end of third week $(0.183 \pm 0.106$, difference is significant). For detailed statistical analysis, see Supplementary Material 2.

\subsection{Photochemical efficiency and excitation energy allocation}

During Cd treatment, the maximal quantum efficiency of PSII reaction centres $\left(\mathrm{F}_{\mathrm{v}} / \mathrm{F}_{\mathrm{m}}\right)$ decreased continuously up to the middle of the second week, but then increased until it had reached the level of Ctrl plants. The $\mathrm{F}_{\mathrm{m}}$ level was more affected (from $0.661 \pm 0.081$ at the $9^{\text {th }}$ day to $0.885 \pm 0.105$ at the $21^{\text {st }}$ day), while $\mathrm{F}_{0}$ was less variable (from $0.316 \pm$ 0.057 at the $9^{\text {th }}$ day to $0.220 \pm 0.026$ at the $21^{\text {st }}$ day). Ctrl plants did not show significant changes during the experimental time, $\mathrm{F}_{0}$ and $\mathrm{F}_{\mathrm{m}}$ values were stable $\left(\mathrm{F}_{0}: 0.190 \pm 0.015\right.$ and $\left.\mathrm{F}_{\mathrm{m}}: 0.920 \pm 0.096\right)$.

Concerning the excitation energy allocation, no significant changes were found in Ctrl plants, except for the decrease of $\Phi_{\mathrm{NPQ}}$ in the third week of treatment. In Cad plants, the changes in $\Phi_{\text {PSII }}$ were similar to that of $\mathrm{F}_{\mathrm{v}} /$ $\mathrm{F}_{\mathrm{m}}$ (Figure $3 \mathrm{~A}$ ). $\Phi_{\mathrm{NF}}$ changed antiparallel to $\Phi_{\mathrm{PSII}}$ in Cad plants, while it did not differ significantly from zero in Ctrls (Figure 3C). $\Phi_{\mathrm{NPO}}$ showed an increasing trend from the second half of the first week, and exceeded the level of Ctrl from the second week (Figure 3B). Fluorescence and constitutive heat dissipation $\left(\Phi_{\mathrm{f}, \mathrm{D}}\right)$ rose in the initial phase of $\mathrm{Cd}$ treatment and only showed a trend towards decrease during the fourth week of treatment (Figure 3D). For detailed statistical analysis, see Supplementary Material 3.

\subsection{Oxidative stress and antioxidative defence}

The concentration of MDA strongly increased in Cad plants compared to Ctrl. It reached $241.0 \pm 19.8 \%$ of the well-developed Ctrl up to the end of the second week of treatment (Figure 4A). However, it decreased in the third and fourth week, by the end of which the difference was no longer significant. For detailed statistical analysis, see Supplementary Material 3.

Cd treatment reduced the APX activity in the acute phase of the stress, but the activity started to increase from the first week. Thus, the APX activity became significantly higher in Cad leaves compared to the unchanged activity of Ctrl leaves in the third and fourth week (Figure 4B).

Cd treatment generally reduced the total SOD activity (Table 1). Nevertheless, there were fluctuations: there was no significant difference between $\mathrm{Ctrl}$ and Cad plants at the $14^{\text {th }}$ and $29^{\text {th }}$ day of treatment, but SOD activity was significantly lower in the remaining experimental time. In native gels, four SOD isoforms were separated (Figure 5).
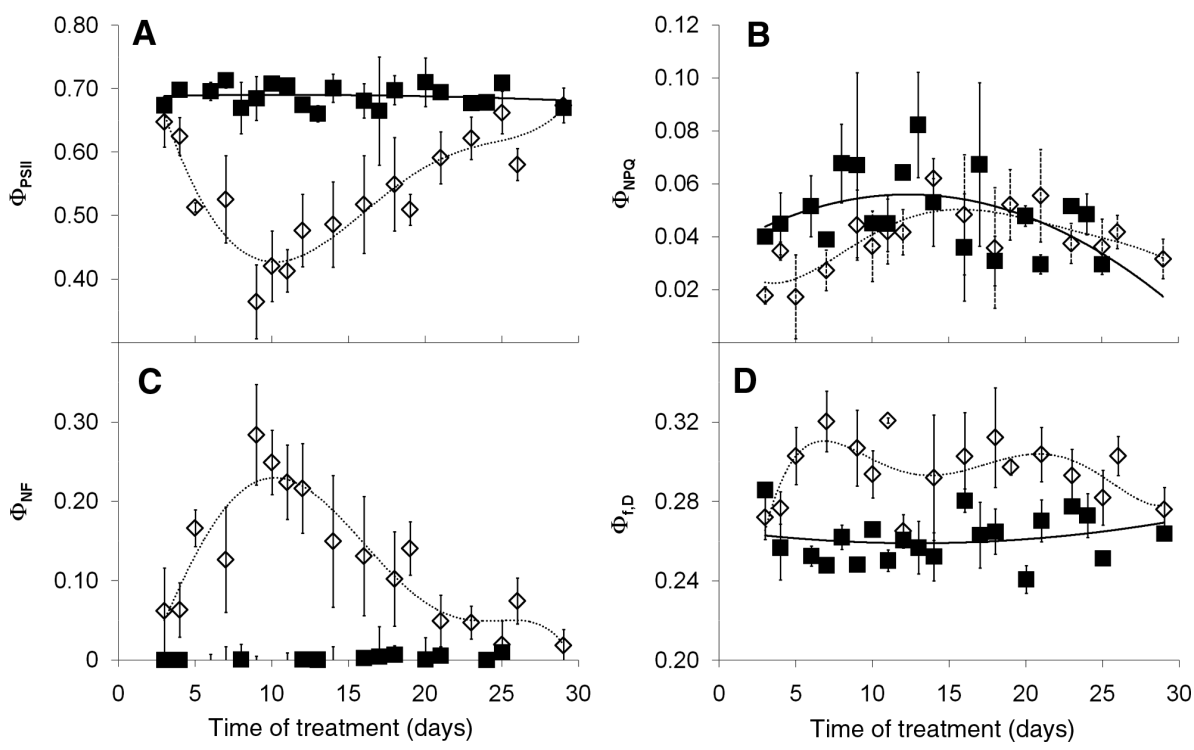

Figure 3: Differences in the allocation of excitation energy in Ctrl (filled marks) and Cad (open marks) leaves during the treatment period. (A) Photochemical quenching $\left(\Phi_{\mathrm{PSII}}\right)$; (B) energization-dependent non-photochemical quenching $\left(\Phi_{\mathrm{NPO}}\right)$; (C) non-radiative dissipation related to the inactivation of PSII reaction centres $\left(\Phi_{\mathrm{NF}}\right)$; (D) fluorescence and constant heat dissipation of the photosynthetic apparatus $\left(\Phi_{\mathrm{f}, \mathrm{D}}\right)$. Error bars represent SD values, $n=5$. 


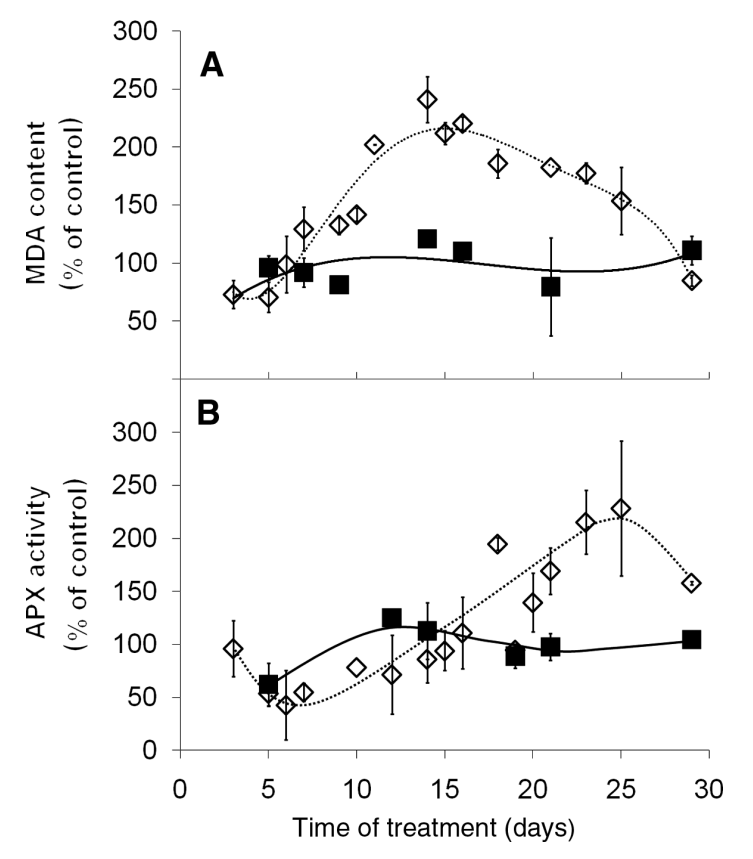

Figure 4: Changes in the oxidative stress defense. Changes in the malondialdehyde (MDA) content (A) and ascorbate peroxidase (APX) activity (B) in Ctrl (filled marks) and Cad (open marks) leaves during the treatment period. Average values of the Ctrls were: $82.6 \pm 12.2$ nmol MDA g ${ }^{-1}$ fresh weight and $9.0 \pm 4.1 \mathrm{pmol}$ ascorbate $\mu \mathrm{g}^{-1}$ protein $\min ^{-1}$, respectively. Error bars represent SD values, $n=8$.

The activities of isoforms I, III, and IV were the most sensitive to $\mathrm{Cd}$ treatment (Figure $6 \mathrm{~A}-\mathrm{C}$ ), while no significant differences from the Ctrl were detected in the activity of isoform II (not shown). Fluctuations were found in the activities of isoforms III and IV: their trend was the same in Cad and Ctrl leaves, but there was a delay of about 5 days in the appearance of the activity maxima in Cad compared to Ctrl leaves.

In contrast to total SOD activity, total POD activity increased nearly continuously in Cad leaves during the experimental time (Table 1). On native gels, 12 POD isoforms were identified (Figure 5), three of which (I, II and VII) were not present in the first 2 weeks of treatment, and the amounts of all isoforms increased during the hardening period (from the second week). Cd treatment affected the activities of the isoforms differently. Four major groups can be distinguished. In the first group (isoforms I, III and IV), the activities did not differ significantly in Cad and Ctrl leaves (not shown). In the second group (isoforms VIII, X, XII and partially V), the activities were higher in Cad leaves in the first 2 weeks of treatment, but did not differ significantly from those of the Ctrl leaves in the last 2 weeks (Figure 7A). In the third group (isoforms II, VI and VII), the activities did not differ significantly from the Ctrl in the first 2 weeks, but were significantly lower in the

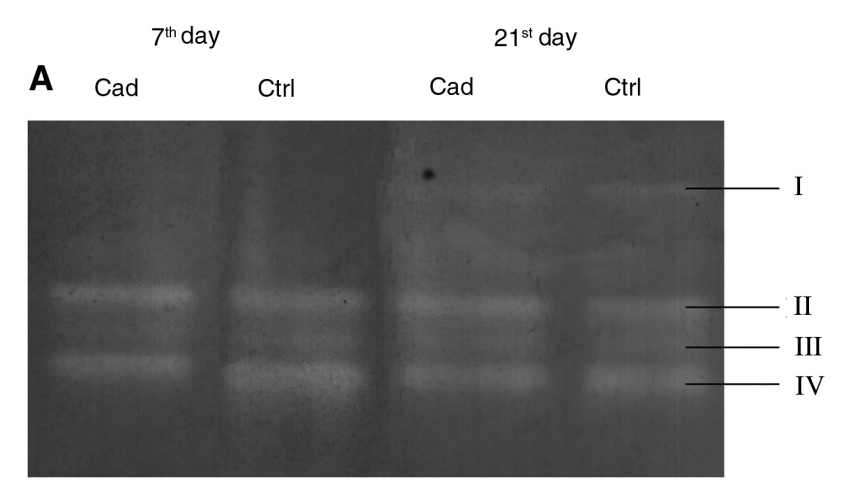

B

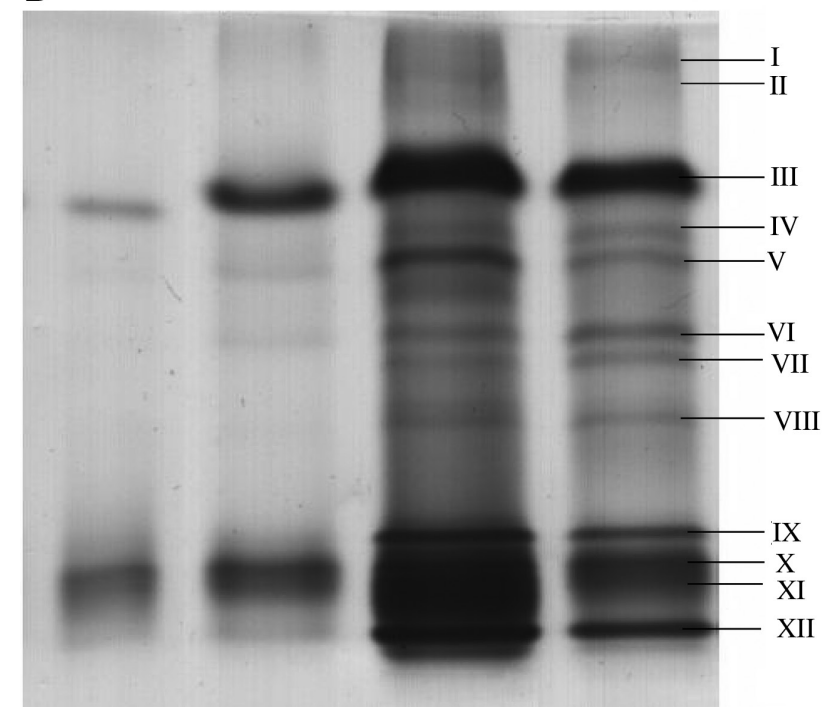

Figure 5: Separation of the isoforms of antioxidative enzymes. Superoxide dismutase (A; SOD) and peroxidase (B; POD) isoforms of $\mathrm{Ctrl}$ and $\mathrm{Cad}$ leaves separated on native gels. Numbers indicate the isoforms both of SOD and POD.

last 2 weeks (Figure 7B). In the fourth group (isoforms IX and XI), activities were significantly higher in Cad leaves during the entire time of the experiment (Figure 7C).

\section{Discussion}

Poplar plants were able to survive long-term exposure to $10 \mu \mathrm{M} \mathrm{Cd}$ in the nutrient solution. As Cd induces acute damage, the observed long-term survival requires inducible defence mechanisms against the direct and indirect effects of $\mathrm{Cd}$.

\subsection{Metal re-distribution and hardening}

$\mathrm{Cd}$ is known to cause many of its effects indirectly by influencing metal distribution [3]. In our experiment, 


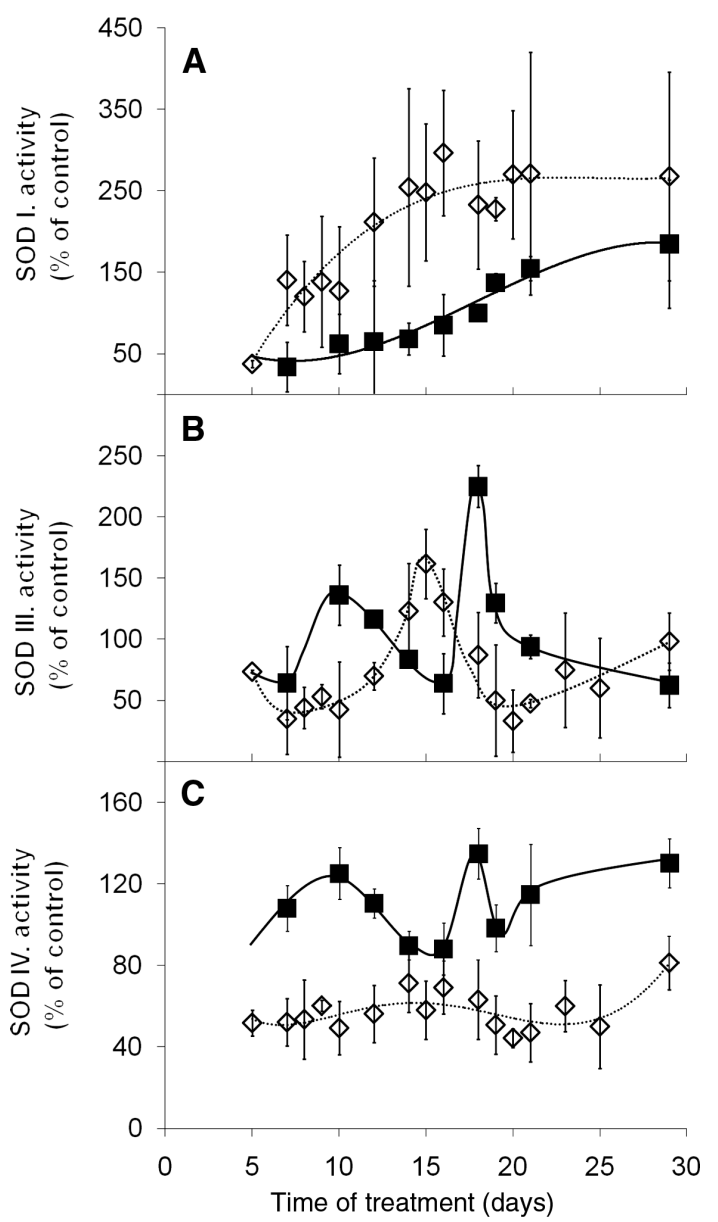

Figure 6: Changes in the activities of selected superoxide dismutase (SOD) isoforms representing three different types of changes under long-term $\mathrm{Cd}$ treatment; $(A)$ increase in activity in response to treatment; (B) fluctuating activity; (C) reduced activity compared to the corresponding Ctrls. Normalised values were: (A) $37.1 \pm 0.0$ pixel density $\mu \mathrm{g}^{-1}$ protein; (B) $136.2 \pm 15.4$ pixel density $\mu \mathrm{g}^{-1}$ protein; (C) $569.9 \pm 212.9$ pixel density $\mu \mathrm{g}^{-1}$ protein. Error bars represent SD values, $n=8$.

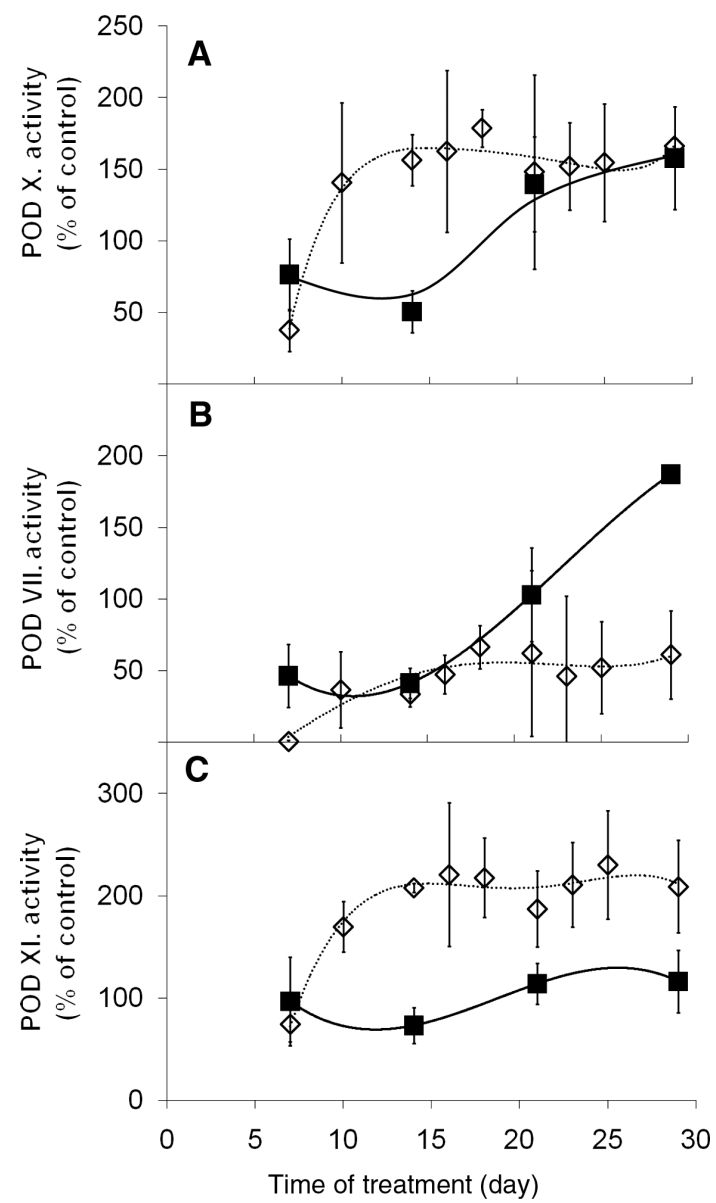

Figure 7: Changes in the activities of selected (peroxidase) POD isoforms representing three different types of changes under long-term Cd treatment; (A) activity increase in both Ctrl and Cad leaves; (B) activity decrease, and (C) activity increase under $C d$ treatment. Normalised values were: (A) $1168.1 \pm 238.0$ pixel density $\mu^{-1}$ protein; (B) $4582.0 \pm 1634.3$ pixel density $\mu \mathrm{g}^{-1}$ protein; (C) $11228.5 \pm 3779.3$ pixel density $\mu \mathrm{g}^{-1}$ protein. Error bars represent SD values, $n=8$.

Table 1: Total superoxide dismutase (SOD) and peroxidase (POD) activities in Ctrl and Cad leaves.

\begin{tabular}{lrrrr}
\hline & & SOD & & POD \\
\cline { 2 - 5 } & \multicolumn{1}{c}{ Ctrl } & Cad & \multicolumn{1}{c}{ Ctrl } & Cad \\
\cline { 2 - 5 } 7 Days & $94.6 \pm 18.8^{\mathrm{b}}$ & $36.3 \pm 25.0^{\mathrm{a}}$ & $110.6 \pm 14.8^{\mathrm{b}}$ & $58.7 \pm 22.7^{\mathrm{a}}$ \\
14 Days & $121.6 \pm 14.9^{\mathrm{b}, \mathrm{c}}$ & $98.5 \pm 8.2^{\mathrm{b}}$ & $89.4 \pm 14.8^{\mathrm{a}}$ & $258.5 \pm 69.2^{\mathrm{c}}$ \\
21 Days & $96.4 \pm 17.6^{\mathrm{b}}$ & $64.8 \pm 14.7^{\mathrm{a}, \mathrm{b}}$ & $477.2 \pm 109.9^{\mathrm{d}}$ & $365.2 \pm 56.7^{\mathrm{c}}$ \\
29 Days & $126.9 \pm 21.8^{\mathrm{b}, \mathrm{c}}$ & $111.4 \pm 2.1^{\mathrm{c}}$ & $307.0 \pm 79.0^{\mathrm{c}}$ & $593.5 \pm 87.0^{\mathrm{e}}$ \\
\hline
\end{tabular}

Values are given in percent of the activity of fully grown Ctrl leaves (SOD: $6565.66 \pm 594.03$ pixel density $\mu \mathrm{g}^{-1}$ protein; POD: $39,837 \pm 9337$ pixel density $\mu \mathrm{g}^{-1}$ protein). One-way ANOVAs with Tukey-Kramer post-hoc tests were performed on data $(\mathrm{p}<0.05)$. Italic values represent standard deviations, $n=8$. Superscript letters indicate the subgroups according to the post-hoc test.

Cd treatment strongly reduced the concentration of Fe, slightly decreased that of $\mathrm{Mn}$, but increased the $\mathrm{Zn}$ content in leaves of poplar. As severe Mn deficiency produces effects similar to those of Cd [34], the observed slight Mn deficiency may contribute to the Cd caused inhibition of photosynthesis, particularly the PSII activity. Mn and Cd 
share a common transporter, NRAMP5, thus the presence of Cd can inhibit Mn transport processes in the plants [35]. In the $\mathrm{Cd} / \mathrm{Zn}$ hyperaccumulator Thlaspi caerulescens, the presence of Cd was found to inhibit the uptake of Fe, Mn and $\mathrm{Zn}$ by interfering with the regulation of ZIP family transporter genes [36]. In contrast, the increased $\mathrm{Zn}$ content of $\mathrm{Cd}$ treated Populus leaves may be related to the Cd induced transcription of root Zn transporter ZIP9 [37].

From the point of view of both damage to and hardening of photosynthesis, the most important event is the $\mathrm{Cd}$ induced Fe deficiency in leaves $[3,4]$ which is also manifested in the chloroplasts [22]. In fact, the translocation of Fe from roots to the shoots was negligible during the entire experimental period. This may be related to the $\mathrm{Cd}$ induced down-regulation of the expression the citrate transporter FRD3 in the root xylem parenchyma, which plays a key role in citrate efflux into the xylem and thus in the root-to-shoot Fe translocation [38]. As Fe translocation did not recover under the continued Cd stress, the driving force of the later recovery cannot originate from an increased $\mathrm{Fe}$ content in the shoot. Indeed, the restoration of some Fe-requiring physiological parameters indicates that the re-distribution of Fe in the mesophyll cells plays an important role, which process also involves the allocation of Fe into the chloroplasts (Figure 1B, [39]). Fe acquisition by chloroplasts can also be monitored by the slow increase in the Chl content [40] and by the recovery of photochemical activity.

\subsection{Changes in excitation energy allocation during stress hardening}

Acute Cd stress inhibited Chl accumulation and decreased the $\mathrm{Chl} a / b$ ratio due to its effects on the developmental stability and activity of the reaction centres, but did not significantly change the carotenoid/Chl ratio. Together with the developmental disturbances in thylakoids, the $\mathrm{F}_{\mathrm{v}} / \mathrm{F}_{\mathrm{m}}$, i.e. the maximal quantum efficiency of PSII centres, also declined due to the alterations in both $\mathrm{F}_{0}$ and $\mathrm{F}_{\mathrm{m}}$. Since $\mathrm{Cd}$ inhibits the electron transport in PSII reaction centres [7], the transfer of excitation energy to molecular oxygen can increase, thereby leading to damage in the D1 protein. The increase of $\Phi_{f, D}$ together with the elevated level of $F_{0}$ indicated that the connexion between the PSII reaction centres and the antennae [41] was severed. Nevertheless, $\mathrm{F}_{\mathrm{m}}$ was more severely affected in this period, indicating an inhibition-based NPQ of the reaction centres [27]. The strongly increased $\Phi_{\mathrm{NF}}$ together with the decreased $\mathrm{F}_{\mathrm{m}}$ and $\Phi_{\mathrm{PSII}}$ means that quenching by the inactive reaction centres becomes the most important mechanism of excitation energy quenching in the acute period of $\mathrm{Cd}$ stress. The diminished function of PSII, the decreased synthesis of PSI centres together with the developing oxidative stress, as evidenced by the increasing MDA-content (Figure 4A), can be a self-enhancing driving force in the formation of quenching centres.

In the hardening period, the opposite trend, i.e. the decrease in PSII inactivation and increase in PSII quantum efficiency, indicates the recovery of photosynthetic activity. Whereas the concentration of Fe did not changed significantly in the leaves, the chloroplast-directed re-distribution of Fe may have been of special importance in the hardening process. Any increase in the chloroplast $\mathrm{Fe}$ content results in an increase of the strongly Fe-dependent processes such as the biosynthesis of Chls and the formation of Fe-containing PSI complexes [26]. In addition to the increase in $\Phi_{\text {PSII }}$, the observed increase in the $\beta$-carotene/ $\mathrm{Chl}$ and $\mathrm{Chl} a / b$ ratios indicates a de novo formation of reaction centres. The elevated concentration of zeaxanthin under light conditions contributed to the increase of $\Phi_{\mathrm{NPQ}}$. Nevertheless, it has to be noticed that the $\Delta \mathrm{pH}$-dependent quenching was low during the entire experimental time, even in Ctrl samples, because of the applied low light intensity (Cd treated plants are light sensitive, see: [42]).

\subsection{Antioxidative defence}

Cd has been shown to accumulate in the cytoplasm and in the cell walls of Populus $\times$ canescens leaves [43]. Since $\mathrm{Cd}$ cannot participate in Fenton reactions, it generates an oxidative burst indirectly by interacting with the signalling pathway of calmodulin/ $\mathrm{Ca}^{2+}$-dependent protein kinases [44]. Peroxidases are also important in scavenging $\mathrm{H}_{2} \mathrm{O}_{2}$, especially in the cell wall. In fact, the relatively fast induction of some POD isoforms in the high mobility region upon the onset of Cd stress indicates that they may be in the first line of protection against ROS [15]. Marmiroli et al. [45] showed that peroxidase 5 is among the first proteins induced by $\mathrm{Cd}$ treatment in Populus spp. As all class III peroxidases contain the hem prosthetic group, the limited availability of Fe may also have contributed to the alteration in their activity. Acidic peroxidases, which are involved in lignin synthesis [18] were not inactivated. Moreover, the high mobility, and potentially acidic isoforms showed increased activity under Cd stress. In fact, they may also have a role in increasing leaf dry weight, since they contribute to secondary cell wall biosynthesis. An increase in the monomeric constituents of the secondary cell wall has previously been become obvious from the elevated level of blue-emitting cell wall phenolics, like ferulic acid [42, 46]. 
During long-term Cd treatment, poplar plants were able to overcome oxidative damage. Thus, following the acute phase of Cd stress, lipid peroxidation decreased. The trend of the changes in the MDA content was similar to that of $\Phi_{\mathrm{NF}}$ indicating the involvement of ROS both in the development of membrane damage and in PSII inactivation. According to Giacomelli et al. [47], APX and SOD isoforms are of importance in the elimination of ROS in chloroplasts. The rise in the activity of APX was observed in parallel to the decline of lipid peroxidation and the increase of $\Phi_{\text {PSII }}$. The separated SOD isoforms can be identified as I: MnSOD, II: Cu/ZnSOD, III: FeSOD and IV: $\mathrm{Cu} / \mathrm{ZnSOD}$ [48-50]. As, in contrast to the MnSOD that is present in peroxisomes, mitochondria and cell wall [51], the activities of chloroplast $\mathrm{Cu} / \mathrm{ZnSOD}$ isoforms (II and IV) did not increase during the experiment, their role in Cd stress alleviation may be less important in poplar. Fluctuations in the activity of the isoform III, identified as FeSOD, might be a result of the re-distribution of the intracellular Fe content. FeSOD is only present in the chloroplasts [51], thus any changes in its activity are strongly connected to the Fe content of chloroplasts. In Cad leaves, maximum activity of FeSOD appeared when APX activity reached the level of Ctrl leaves and $\Phi_{\mathrm{NF}}$ started to decline, indicating that the FeSOD isoform is of importance in hardening. Thus, elimination of ROS via the water-water cycle in chloroplasts [13] may have induced a self-enhancing process: the decreased amount of ROS allowed the restoration of PSII reaction centres, and increasing photosynthetic activity produced further reducing capacity for ROS elimination.

\section{Conclusion}

In poplar, long-term $\mathrm{Cd}$ treatment leads to hardening that alleviates the acute damage as evidenced by the decrease in leaf MDA content and recovery of PSII activity. Activation of antioxidative enzymes, especially POD and APX, appears to play a role in the elimination of ROS. Re-distribution of leaf $\mathrm{Fe}$, and its allocation to the chloroplasts in particular, promote the recovery of photosynthetic structures and activity, which, in fact, also contributes to the requirement of the antioxidative defence for reductants. Thus, it allows increasing Cd tolerance of poplar by elevating Fe supply [22] and/or by overexpressing antioxidant [52] or ROS-scavenging enzymes [53, 54].

Acknowledgments: We would like to thank Zsuzsanna Ostorics for technical assistance. This work was supported by the National Office for Research, Development, and Innovation, Hungary (NKFIH-OTKA, PD-112047). Á. Solti was also supported by the Bolyai János Research Scholarship of the Hungarian Academy of Sciences (BO/00207/15/4).

\section{References}

1. Nawrot T, Plusquin M, Hogervorst J, Roels HA, Celis H, Thijs L, et al. Environmental exposure to cadmium and risk of cancer: a prospective population-based study. Lancet Oncol 2006;7:119-26.

2. Andresen E, Küpper H. Cadmium toxicity in plants. In: Sigel A, Sigel H, Sigel RK, editors. Cadmium: from toxicity to essentiality. The Netherlands: Springer, 2013:395-413.

3. Siedlecka A, Krupa Z. Cd/Fe interaction in higher plants - its consequences for the photosynthethic apparatus. Photosynthetica 1999;36:321-31.

4. Fodor F, Gáspár L, Morales F, Gogorcena Y, Lucena JJ, Cseh $E$, et al. The effect of two different iron sources on iron and cadmium allocation in cadmium exposed poplar plants (Populus alba L.). Tree Physiol 2005;25:1173-80.

5. Fagioni M, D’Amici GM, Timperio AM, Zolla L. Proteomic analysis of multiprotein complexes in the thylakoid membrane upon cadmium treatment. J Prot Res 2009;8:310-26.

6. Basa B, Lattanzio G, Solti Á, Tóth B, Abadía J, Fodor F, et al. Changes induced by cadmium stress and iron deficiency in the composition and organization of thylakoid complexes in sugar beet (Beta vulgaris L.). Environ Exp Bot 2014;101:1-11.

7. Sigfridsson KG, Bernát G, Mamedov F, Styring S. Molecular interference of $\mathrm{Cd}^{2+}$ with photosystem II. Biochim Biophys Acta 2004;1659:19-31.

8. Siedlecka A, Krupa Z. Interaction between cadmium and iron and its effects on photosynthetic capacity of primary leaves of Phaseolus vulgaris. Plant Physiol Biochem 1996;34:833-41.

9. Gallego SM, Pena LB, Barcia RA, Azpilicueta CE, lannone MF, Rosales EP, et al. Unravelling cadmium toxicity and tolerance in plants: Insight into regulatory mechanisms. Environ Exp Bot 2012;83:33-46.

10. Murata N, Takahashi S, Nishiyama Y, Allakhverdiev SI. Photoinhibition of photosystem II under environmental stress. Biochim Biophys Acta 2006;1767:414-21.

11. Chow WS, Lee HY, He J, Hendrickson L, Hong YM, Matsubara S. Photoinactivation of photosystem II in leaves. Photosynth Res 2005;84:35-41.

12. Shinopoulos KE, Brudvig GW. Cytochrome $b_{559}$ and cyclic electron transfer within photosystem II. Biochim Biophys Acta 2012;1817:66-75.

13. Miyake C. Alternative electron flows (water-water cycle and cyclic electron flow around PSI) in photosynthesis: Molecular mechanisms and physiological functions. Plant Cell Physiol 2010;51:1951-63.

14. Gratão PL, Polle A, Lea PJ, Azevedo RA. Making the life of heavy metal-stressed plants a little easier. Function Plant Biol 2005;32:481-94.

15. Smeets K, Cuypers A, Lambrechts A, Semane B, Hoet P, Van Laere $A$, et al. Induction of oxidative stress and antioxidative mechanisms in Phaseolus vulgaris after Cd application. Plant Physiol Biochem 2005;43:437-44. 
16. Dai HP, Shan CJ, Lu C, Jia GL, Wei AZ, Sa WQ, et al. Response of antioxidant enzymes in Populus $\times$ canescens under cadmium stress Pak J Bot 2012;44:1943-9.

17. Yang Y, Li X, Yang S, Zhou Y, Dong C, Ren J, et al. Comparative physiological and proteomic analysis reveals the leaf response to cadmium-induced stress in poplar (Populus yunnanensis). PLoS One 2015;10:e0137396.

18. Chamseddine M, Wided BA, Guy H, Marie-Edith C, Fatma J. Cadmium and copper induction of oxidative stress and antioxidative response in tomato (Solanum lycopersicon) leaves. Plant Growth Regul 2009;57:89-99.

19. Kieffer P, Schröder P, Dommes J, Hoffmann L, Renaut J, Hausman J-F. Proteomic and enzymatic response of poplar to cadmium stress. J Proteom 2009;72:379-96.

20. Jakovljević T, Cvjetko Bubalo MC, Orlović S, Sedak M, Bilandžić $\mathrm{N}$, Brozinčević I, et al. Adaptive response of poplar (Populus nigra L.) after prolonged Cd exposure period. Environ Sci Pollut Res 2014;21:3792-802.

21. Pilipović A, Nikolić N, Orlović S, Petrović N, Kristić B. Cadmium phytoextraction potential of poplar clones (Populus spp.). Z Naturforsch 2005;60c:247-51.

22. Sárvári É, Solti Á, Basa B, Mészáros I, Lévai L, Fodor F. Impact of moderate Fe excess under $\mathrm{Cd}$ stress on the photosynthetic performance of poplar (Populus jaquemontiana var. glauca cv. Kopeczkii). Plant Physiol Biochem 2011;49:499-505.

23. Smith GF, McCurdy WH, Diehl H. The colorimetric determination of iron in raw and treated municipal water supplies by use of 4:7-diphenyl-1:10-phenanthroline. Analyst 1952;77:418-22.

24. Porra RJ, Thompson WA, Kriedman PE. Determination of accurate excitation coefficient and simultaneous equations for assaying chlorophylls $a$ and $b$ extracted with four different solvents: verification of the concentration of chlorophyll standards by atomic absorption spectroscopy. Biochim Biophys Acta 1989;975: 384-94.

25. Tóth VR, Mészáros I, Veres SZ, Nagy J. Effects of the available nitrogen on the photosynthetic activity and xanthophyll cycle pool of maize in field. J Plant Physiol 2002;159:627-34.

26. Solti Á, Gáspár L, Mészáros I, Szigeti Z, Lévai L, Sárvári É. Impact of iron supply on the kinetics of recovery of photosynthesis in Cd-stressed poplar (Populus glauca). Ann Bot 2008;102:771-82.

27. Hendrickson L, Förster B, Pogson BJ, Chow WS. A simple chlorophyll fluorescence parameter that correlates with the rate coefficient of photoinactivation of Photosystem II. Photosynth Res 2005;84:43-9.

28. Solti Á, Lenk S, Mihailova G, Mayer P, Barócsi A, Georgieva K. Effects of habitat light conditions on the excitation quenching pathways in desiccating Haberlea rhodopensis leaves: an Intelligent FluoroSensor study. J Photochem Photobiol B 2014;130:217-25.

29. Heath R, Packer L. Photoperoxidation in isolated chloroplasts. Kinetics and stoichiometry of fatty acid peroxidation. Arch Biochem Biophys 1968;125:180-98.

30. Nakano Y, Asada K. Hydrogen peroxide is scavenged by ascorbate-specific peroxidase in spinach chloroplasts. Plant Cell Physiol 1981;22:867-80.

31. Giannopolitis CN, Ries SK. Superoxide dismutases I.: Occurrence in higher plants. Plant Physiol 1977;59:309-14.

32. Laemmli UK. Cleavage of structural proteins during assembly of the head of bacteriophage T4. Nature 1970;227:680-5.
33. Rao MV, Paliyath G, Ormrod DP. Ultraviolet-B- and ozoneinduced biochemical changes in antioxidant enzymes of Arabidopsis thaliana. Plant Physiol 1996;110:125-36.

34. Solti Á, Sárvári É, Tóth B, Basa B, Lévai L, Fodor F. Cd affects the translocation of some metals either Fe-like or Ca-like way in poplar. Plant Physiol Biochem 2011;49:494-8.

35. Sasaki A, Yamaji N, Yokosho K, Ma JF. Nramp5 is a major transporter responsible for manganese and cadmium uptake in rice. Plant Cell 2012;24:2155-67.

36. Küpper H, Kochian LV. Transcriptional regulation of metal transport genes and mineral nutrition during acclimatization to cadmium and zinc in the $\mathrm{Cd} / \mathrm{Zn}$ hyperaccumulator, Thlaspi caerulescens (Ganges population). New Phytol 2010;185:114-29.

37. Weber M, Trampczynska A, Clemens S. Comparative transcriptome analysis of toxic metal responses in Arabidopsis thaliana and the $\mathrm{Cd}^{2+}$-hypertolerant facultative metallophyte Arabidopsis halleri. Plant Cell Environ 2006;29:950-63.

38. Yamaguchi H, Fukuoka H, Arao T, Ohyama A, Nunome T, Miyatake K, et al. Gene expression analysis in cadmiumstressed roots of a low cadmium-accumulating solanaceous plant, Solanum torvum. J Exp Bot 2010;61:423-37.

39. Molins H, Michelet L, Lanquar V, Agorio A, Giraudat J, Roach J, et al. Mutants impaired in vacuolar metal mobilization identify chloroplasts as a target for cadmium hypersensitivity in Arabidopsis thaliana. Plant Cell Environ 2013;36:804-17.

40. Mikami Y, Saito A, Miwa E, Higuchi K. Allocation of Fe and ferric chelate reductase activities in mesophyll cells of barley and sorghum under Fe-deficient conditions. Plant Physiol Biochem 2011;49:513-9.

41. Gáspár L, Sárvári É, Morales F, Szigeti Z. Presence of 'PSI free' $\mathrm{LHCl}$ and monomeric LHCII and subsequent effects on fluorescence characteristics in lincomycin treated maize. Planta 2006;223:1047-57.

42. Solti Á, Gáspár L, Vági P, Záray G, Fodor F, Sárvári É. Cd, Fe, and light sensitivity: Interrelationships in Cd-treated Populus. OMICS - J Integrat Biol 2011;15:811-18.

43. Dai H-P, Shan C, Wei Y, Liang J-G, Yang T-X, Sa W-Q, et al. Subcellular localization of cadmium in hyperaccumulator Populus $\times$ canescens. Afr J Biotechnol 2012;11:3779-87.

44. Olmos E, Martínez-Solano JR, Piqueras A, Hellín E. Early steps in the oxidative burst induced by cadmium in cultured tobacco cells (BY-2 line). J Exp Bot 2003;54:291-301.

45. Marmiroli M, Imperiale D, Maestri E, Marmiroli N. The response of Populus spp. to cadmium stress: Chemical, morphological and proteomics study. Chemosphere 2013;93:1333-44.

46. Morales F, Cerovic ZG, Moya I. Time-resolved blue-green fluorescence of sugar beet (Beta vulgaris L.) leaves. Spectroscopic evidence for the presence of ferulic acid as the main fluorophore of the epidermis. Biochim Biophys Acta 1996;273:251-62.

47. Giacomelli L, Masi A, Ripoll DR, Lee MJ, van Wijk KJ. Arabidopsis thaliana deficient in two chloroplast ascorbate peroxidases shows accelerated light-induced necrosis when levels of cellular ascorbate are low. Plant Mol Biol 2007;65:627-44.

48. Bernardi B, Nali C, Ginestri P, Pugliesi C, Lorenzini G, Durante M. Antioxidant enzyme isoforms on gels in two poplar clones differing in sensitivity after exposure to ozone. Biol Plant 2004;48:41-8.

49. Bertrand M, Poirier I. Photosynthetic organisms and excess of metals. Photosynthetica 2005;43:345-53. 
50. Marron N, Maury S, Rinaldi C, Brignolas F. Impact of drought and leaf development stage of enzymatic antioxidant system of two Populus deltoides x nigra clones. Ann Forest Sci 2006;63:323-7.

51. Miller AF. Superoxide dismutases: Ancient enzymes and new insights. FEBS Lett 2012;586:585-95.

52. Rizwan M, Ali S, Abbas T, Zia-ur-Rehman M, Hannan F, Keller C, et al. Cadmium minimizationinwheat: a criticalreview. Ecotoxicol Environ Safety 2016;130:50-3.

53. Bartels D. Targeting detoxification pathways: an efficient approach to obtain plants with multiple stress tolerance? Trends Plant Sci 2001;6:284-6.
54. Éva C, Solti Á, Oszvald M, Tömösközi-Farkas R, Nagy B, Horváth G, et al. Improved reactive aldehyde, salt and cadmium tolerance of transgenic barley due to the expression of aldo-keto reductase genes. Acta Physiol Plant 2016;38:99.

Supplemental Material: The online version of this article (DOI: 10.1515/znc-2016-0092) offers supplementary material, available to authorized users. 